\title{
Temperature Factor Affecting the Abscission Response of Mature Fruit and Leaves to CMN-Pyrazole and Ethephon in 'Hamlin' Oranges
}

\author{
Rongcai Yuan and Jacqueline K. Burns ${ }^{1}$ \\ Horticultural Sciences Department, University of Florida, Institute for Food and Agricultural Sciences, \\ Citrus Research and Education Center, 700 Experiment Station Road, Lake Alfred, FL 33850
}

\begin{abstract}
AdDitional INDEX WORDS. abscission compounds, 5-chloro-3-methyl-4-nitro-1H-pyrazole, Citrus sinensis, ethylene, fruit abscission, fruit detachment force, leaf abscission

AвSTRact. The effect of temperature on the ability of 5-chloro-3-methyl-4-nitro-1H-pyrazole (CMNP) and ethephon to induce ethylene evolution and abscission of mature fruit and leaves was determined using 3-year-old potted 'Hamlin' orange [Citrus sinensis (L.) Osb.] trees in environment-controlled growth rooms in seasons 2001-02 and $2002-03$. Ethylene evolution and abscission of CMNP or ethephon-treated fruit and ethephon-treated leaves were highly temperature dependent. Fruit detachment force (FDF) and fruit ethylene evolution were not affected by application of ethephon at $200 \mathrm{mg} \cdot \mathrm{L}^{-1}$ or $\mathrm{CMNP}$ at $200 \mathrm{mg} \cdot \mathrm{L}^{-1}$ when air temperature was $10{ }^{\circ} \mathrm{C}$ for ethephon treatment or $\leq 15.6{ }^{\circ} \mathrm{C}$ for CMNP treatment. However, ethylene evolution of CMNP or ethephon-treated fruit increased sharply, and FDF decreased drastically as temperature increased from 10 to $26.7^{\circ} \mathrm{C}$ for ethephon treatment or from 15.6 to $26.7^{\circ} \mathrm{C}$ for CMNP treatment. Several 10 hour day/14 hour night temperature regimes were explored to determine the effect of varying daily and nightly temperatures on efficacy and ethylene evolution. At least 3 days of exposure to $21 / 10{ }^{\circ} \mathrm{C}$ were required for $\mathrm{CMNP}$ to effectively loosen fruit, whereas only one day of exposure to $26.7 / 15.6^{\circ} \mathrm{C}$ was enough to induce similar changes. At $21 / 10{ }^{\circ} \mathrm{C}$, CMNP significantly reduced FDF to $<25 \mathrm{~N}$ and markedly enhanced fruit ethylene evolution, regardless of interruption by 1 day of low temperature at $10 / 10{ }^{\circ} \mathrm{C}$ in the first $5 \mathrm{~d}$ after application. Ethephon had no significant effect on leaf ethylene evolution and leaf abscission when temperature was $10^{\circ} \mathrm{C}$, but caused a marked increase in both leaf ethylene evolution and leaf abscission as temperature increased from 10 to $26.7^{\circ} \mathrm{C}$. $\mathrm{CMNP}$ did not stimulate leaf ethylene evolution and leaf abscission regardless of temperature. Chemical names used: 5-chloro-3methyl-4-nitro-1 H-Pyrazole (CMNP); 2-chloroethylphosphonic acid (ethephon).
\end{abstract}

Mechanical harvesting of oranges (Citrus sinensis) would benefit from the use of abscission compounds due to the extremely high fruit detachment force (FDF) of citrus. In oranges, it is well documented that abscission compounds promote fruit loosening and fruit abscission by either releasing ethylene from degradation of compounds themselves, such as ethephon, or inducing ethylene evolution by 'injuring' the fruit peel tissue such as CMN-Pyrazole (CMNP) (Davies et al., 1976; Kossuth and Biggs, 1977). Concomitant with increased ethylene is initiation of gene expression of cellulase and polygalacturonase, de novo synthesis of these two hydrolytic enzymes in the abscission zone, degradation of the cell wall, and finally separation (Goren, 1993; Kazokas and Burns, 1998). Ethephon has been widely used as an abscission agent in many edible crops such as cherries (Prunus cerasus L.) (Bukovac et al., 1969; Flore and Bukovac, 1982; Olien and Bukovac, 1978), and olive (Olea europaea L.) (Denney and Martin, 1994). Ethephon can also effectively loosen mature orange fruit, but sometimes it induces excessive leaf abscission (Kender et al., 2000). CMNP is the only known abscission compound that can selectively loosen mature citrus fruit without causing injury to young tissues or foliage (Holm and Wilson, 1977; Kender, 1998; Wilson, 1973).

It has been reported that temperature during and following application is the most important environmental factor affecting fruit abscission response to ethephon in cherries (Flore and Bukovac, 1982; Olien and Bukovac, 1978; Wittenbach and Bukovac,

Received for publication 26 Mar. 2003. Accepted for publication 26 Nov. 2003. Florida Agricultural Experiment Station journal series R-09060. We gratefully acknowledge the financial support of the Florida Department of Citrus.

1To whom reprint requests should be addressed. e-mail jkbu@lal.ufl.edu.
1973). Temperature influences both absorption of ethephon (Flore and Bukovac, 1982) and degradation of ethephon to ethylene (Biddle et al., 1976; Olien and Bukovac, 1978). Low temperature following application leads to a poor fruit loosening response whereas high temperature results in excessive leaf abscission, gummosis and dieback of terminal growth of cherries (Olien and Bukovac, 1978). Little information is available about the effects of temperature and duration of exposure on the response of fruit to abscission compounds in oranges. Understanding the optimum temperature range for abscission compounds will assist in effectively managing applications under a wide range of temperatures during the harvest season. The objective of this study was to 1) determine the effects of temperature on ethylene evolution of mature 'Hamlin' orange fruit and leaves, fruit loosening, and leaf abscission after application of ethephon and CMNP, and 2) evaluate selected day/night temperature regimes on the response of 'Hamlin' oranges to CMNP.

\section{Materials and Methods}

Plant Material. Three-year-old 'Hamlin' orange trees grafted on 'Swingle' citrumelo [Citrus paradisi Macf. 'Duncan' $\times$ Poncirus trifoliata (L.) Raf.] rootstock growing in 57-L containers were purchased from a local nursery and used for all experiments.

EFFECTS OFTEMPERATURE ONTHE RESPONSE OF ORANGES TOCMNP INSEASON 2001-02 (EXPT.1). To determine the effect of temperature on the ability of CMNP to induce leaf and fruit ethylene evolution, fruit loosening and leaf abscission, 48 potted 'Hamlin' trees with 10 mature fruit each were selected and randomly assigned into environment-controlled growth rooms of eight trees each 
on 3 Dec. 2001. The environment-controlled growth rooms were set at constant air temperatures of 10, 15.6, 18, 21, 24, or 26.7 ${ }^{\circ} \mathrm{C}$. Half of the trees from each environment-controlled growth room were sprayed with CMNP at $200 \mathrm{mg} \cdot \mathrm{L}^{-1}$ containing $0.125 \%$ of the adjuvant Kinetic (Setre Chem. Co., Memphis, Tenn.) using a pressured hand sprayer. The remaining trees from each environment-controlled growth room were sprayed only with $0.125 \%$ Kinetic and served as control. Solutions were applied to the canopy until run-off. The growth rooms were $6.1 \times 3.05$ $\times 3.05 \mathrm{~m}$, and the irradiance was $1000 \mu \mathrm{mol} \cdot \mathrm{m}^{-2} \cdot \mathrm{s}^{-1}$ from 0600 to $1800 \mathrm{HR}$ and completely dark from 1800 to $0600 \mathrm{HR}$. Thus, there were 12 treatments (CMNP and control, 6 temperatures), with 4 trees per treatment. Time course of ethylene evolution of fruit and leaves in situ was determined. Fruit ethylene evolution was determined $0,1,2,3$, and $5 \mathrm{~d}$ after treatment as described in Burns et al. (1999). Briefly, each of two fruit from each tree was selected and enclosed in a 0.87 -L Rubbermaid plastic container and maintained on the tree. On each sampling date, the containers with fruit inside were closed with the plastic lid, and incubated for $2 \mathrm{~h}$. A 1-mL gas sample was withdrawn from the sealed container through the rubber septum affixed to the lid, and ethylene concentration was measured with a gas chromatograph (Hewlett-Packard, Avondale, Pa.) equipped with an activated alumina column and flame ionization detector. For measurement of leaf ethylene evolution, two leaves were selected from each tree, and the petiole of each leaf was carefully slipped through a slit into the hole ( $5 \mathrm{~mm}$ in diameter) of a rubber stopper. The open spaces between the petiole and the rubber stopper were sealed with nonphytotoxic 3145 Mil-A-46146 RTV adhesive/sealant (Dow Corning Co., Midland, Mich.). Each leaf was put into a $60-\mathrm{ml}$ syringe, enclosed by inserting the rubber stopper to the end of syringe and affixing a rubber septum to the head of syringe, and incubated for $2 \mathrm{~h}$ at $0,1,2,3$, and $5 \mathrm{~d}$ after CMNP application. One $\mathrm{mL}$ of gas sample was withdrawn from the sealed syringe through the rubber septum after $2 \mathrm{~h}$ of container closure, and ethylene concentrations were measured as described above. Fruit and leaf abscission were recorded over $5 \mathrm{~d}$, and fruit detachment force (FDF, newtons) was measured $5 \mathrm{~d}$ after application using a digital force gauge (Force Five, Wagner Instruments, Greenwich, Conn.) (Yuan et al., 2001).

EFFECTS OF TEMPERATURE ON THE RESPONSE OF ORANGES TO ETHEPHON IN SEASON 2001-02 (EXPT. 2). A similar experiment was conducted with ethephon to evaluate the effect of temperature on the ability of ethephon to induce leaf and fruit ethylene evolution, fruit loosening and leaf abscission. In this experiment, 32 potted 'Hamlin' trees with 10 mature fruit each were selected and randomly assigned into the environment-controlled growth rooms of eight trees each on 9 Jan. 2002. The environment-controlled growth rooms were set at constant air temperatures of 10, 15.6, 21, or $26.7^{\circ} \mathrm{C}$. Four trees from each environment-controlled growth room were sprayed with ethephon at $200 \mathrm{mg} \cdot \mathrm{L}^{-1}$ containing $0.125 \%$ of the adjuvant Kinetic using a pressured hand sprayer. Another four trees from each environment-controlled growth room were sprayed only with $0.125 \%$ Kinetic and served as control. Solutions were applied to the canopy until run-off. Leaf and fruit ethylene evolution, fruit detachment force, fruit and leaf abscission were determined as described in CMNP experiment.

EFFECTSOFTEMPERATUREONTHERESPONSEOFORANGESTOCMNP INSEASON 2002-03 (EXPT.3). Effects of temperature on the ability of CMNP to induce leaf and fruit ethylene evolution, fruit loosening and leaf abscission were examined in season 2002-03. In this experiment, different day/night temperature regimes were explored.
Briefly, 24 potted 'Hamlin' trees with 10 mature fruit each were selected and randomly assigned into the environment-controlled growth rooms set at day (from 0800 to $1800 \mathrm{HR}$ )/night (from 1800 to $0800 \mathrm{HR}$ ) air temperatures of $15.6 / 10,21 / 10$, or $26.7 / 15.6^{\circ} \mathrm{C}$ on $20 \mathrm{Dec} .2002$. Four trees from each environment-controlled growth room were sprayed with $\mathrm{CMNP}$ at $200 \mathrm{mg} \cdot \mathrm{L}^{-1}$ containing $0.125 \%$ of the adjuvant Kinetic using a pressured hand sprayer. Another four trees from each environment-controlled growth room were sprayed only with $0.125 \%$ Kinetic and served as control. Fruit abscission, fruit detachment force and fruit ethylene evolution were determined as described above.

EFFECTS OF DAYS AT 21/10 OR 26.7/15.6 ${ }^{\circ} \mathrm{C}$ ON THE RESPONSE OF ORANGES TO CMNP (EXPT. 4). Results obtained from Expts. 1 and 3 showed that CMNP effectively loosened fruit when trees were maintained at $21 / 10$ or $26.7 / 15.6{ }^{\circ} \mathrm{C}$ during the $5 \mathrm{~d}$ treatment period, whereas fruit had no response to CMNP when the temperature was $10 / 10^{\circ} \mathrm{C}$. To examine how many days at $21 / 10$ or $26.7 / 15.6^{\circ} \mathrm{C}$ were sufficient for CMNP to loosen fruit, 72 potted 'Hamlin' trees with 10 mature fruit each were selected and randomly assigned into the environment-controlled growth rooms set at day (from 0800 to $1800 \mathrm{HR}$ )/night (from 1800 to $0800 \mathrm{HR}$ ) air temperatures of $21 / 10$ or $26.7 / 15.6{ }^{\circ} \mathrm{C}$ on 30 Dec. 2002 . At

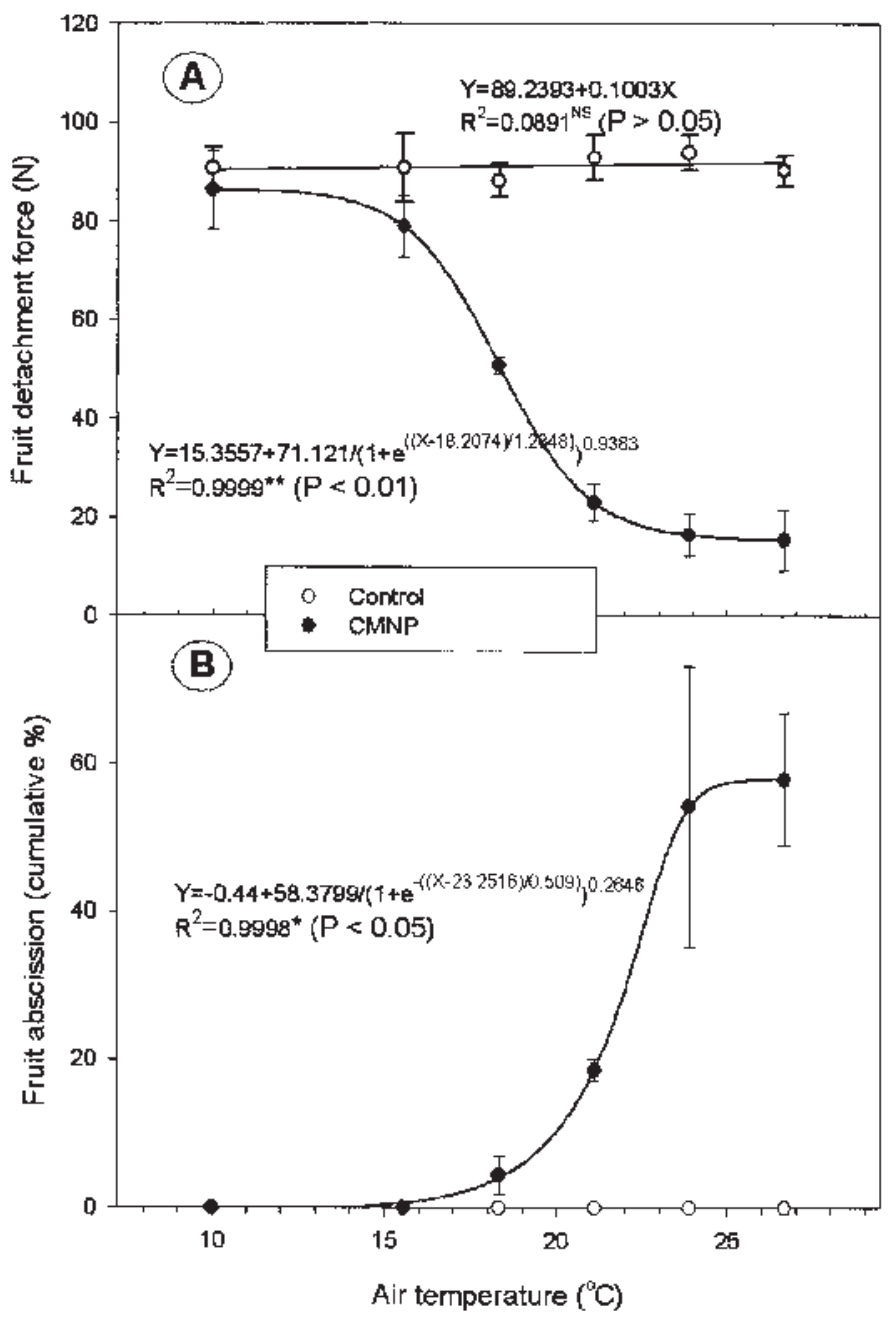

Fig. 1. Effect of temperature on (A) fruit detachment force (FDF) reduction and (B) fruit abscission induced by CMNP at $200 \mathrm{mg} \cdot \mathrm{L}^{-1}$ in 'Hamlin' oranges in season 2001. FDF and fruit abscission were determined $5 \mathrm{~d}$ after application of CMNP. Data are means \pm SE $(n=40$ in $\mathbf{A}$, and 4 in $\mathbf{B}$, respectively). 


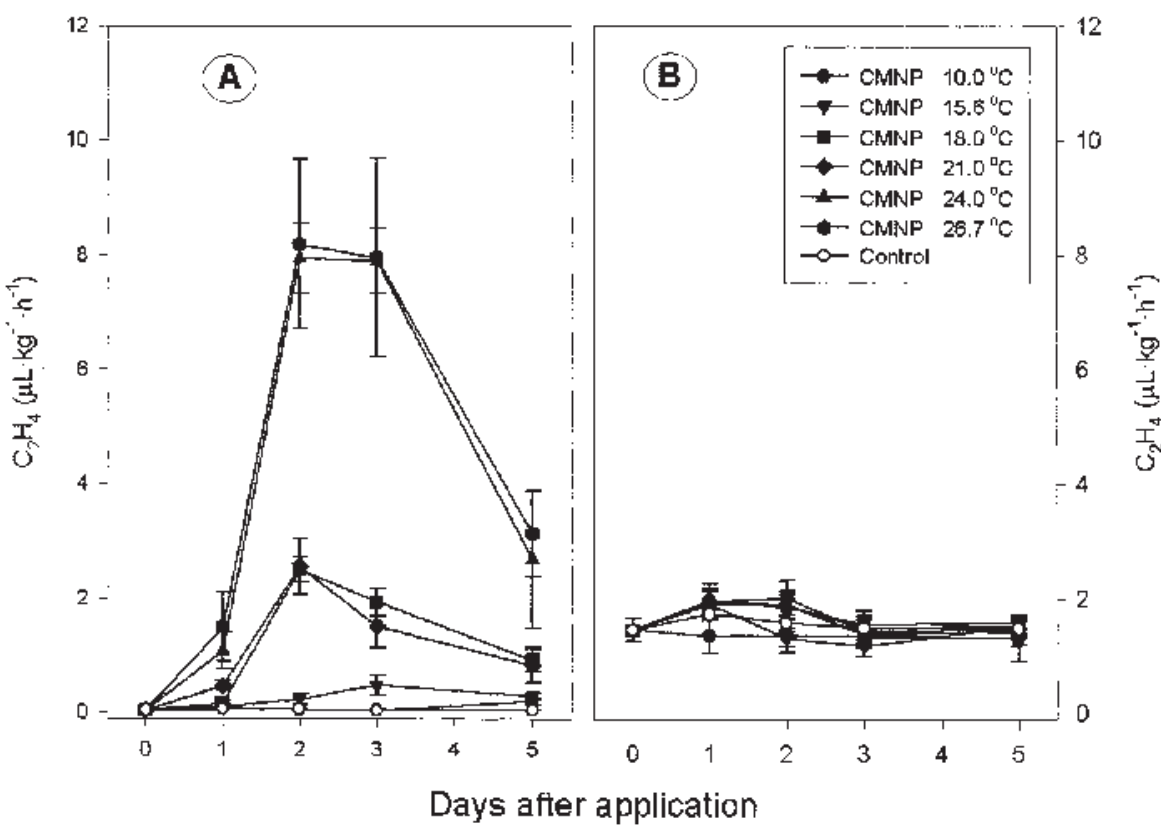

\section{Results}

EFFECTS OFTEMPERATURE ONTHE RESPONSE OFORANGESTOCMNPINSEASON 2001-02 (EXPT. 1). FDF was not affected by application of CMNP at $200 \mathrm{mg} \cdot \mathrm{L}^{-1}$ when air temperature was $15.6{ }^{\circ} \mathrm{C}$ or lower (Fig. 1A). However, as air temperature increased from 15.6 to $24^{\circ} \mathrm{C}$, application of CMNP resulted in a marked reduction in FDF. CMNP did not cause a further reduction in FDF when air temperature increased from 21 to $26.7^{\circ} \mathrm{C}$. Application of CMNP had no influence on fruit abscission when air temperature was $15.6{ }^{\circ} \mathrm{C}$ or lower (Fig. 1B). Fruit abscission induced by CMNP increased from $0 \%$ to $60 \%$ as the air temperature increased from 15.6 to $26.7^{\circ} \mathrm{C}$; the largest changes occurred between 21 and 24 ${ }^{\circ} \mathrm{C}$. Without CMNPapplication, fruit ethylene evolution was not significantly affected by temperature, so all controls were averaged and showed in one line for the convenience
Fig. 2. Effect of temperature on ethylene evolution of (A) fruit and (B) leaves induced by CMNPat $200 \mathrm{mg} \cdot \mathrm{L}^{-1}$ in 'Hamlin' oranges in season 2001-02. Legend in $\mathbf{B}$ applies to $\mathbf{A}$. Data are means $\pm \mathrm{SE}(\mathrm{n}=8)$. Without CMNP application, temperature had no significant impact on fruit or leaf ethylene evolution, so means for all controls were showed.

1, 2, 3 or $4 \mathrm{~d}$ after application of $200 \mathrm{mg} \cdot \mathrm{L}^{-1} \mathrm{CMNP}$ containing $0.125 \%$ of the adjuvant Kinetic or adjuvant alone, four trees were transferred to a $10 / 10{ }^{\circ} \mathrm{C}$ growth chamber for the duration of the $5 \mathrm{~d}$ treatment period. Eight trees remained at $21 / 10$ or $26.7 / 15.6$ ${ }^{\circ} \mathrm{C}$ (4 sprayed with CMNP and 4 with adjuvant alone) for the 5-d period. Fruit abscission, fruit detachment force and fruit ethylene evolution were determined as described previously.

INTERRUPTION BY ONE DAY OF LOW TEMPERATURE DURING AND FOLLOWING APPLICATION OF CMNP ON THE RESPONSE OF ORANGES TO CMNP (ExPT. 5). In total, 24 potted 'Hamlin' trees with 10 mature fruit each were selected and randomly assigned into the environment-controlled growth rooms set at day (from 0800 to $1800 \mathrm{HR}$ )/night (from 1800 to $0800 \mathrm{HR}$ ) air temperatures of 10/10, or $21 / 10^{\circ} \mathrm{C}$ on 14 Jan. 2002. Trees were sprayed with either 200 $\mathrm{mg} \cdot \mathrm{L}^{-1} \mathrm{CMNP}$ containing $0.125 \%$ Kinetic or adjuvant alone. Four treated trees and four control trees were held at $10 / 10$ or $21 / 10^{\circ} \mathrm{C}$ for $5 \mathrm{~d}$. The remaining trees were divided into two temperature interruption treatments. Four treated trees and four control trees were held at $10 / 10^{\circ} \mathrm{C}$ immediately after spray application. After $24 \mathrm{~h}$, the trees were transferred to $21 / 10^{\circ} \mathrm{C}$ for $4 \mathrm{~d}$. Another four treated and four control trees were held for $24 \mathrm{~h}$ at $21 / 10{ }^{\circ} \mathrm{C}$ after spray application, then transferred to $10 / 10^{\circ} \mathrm{C}$ for $24 \mathrm{~h}$, and finally transferred back to $21 / 10^{\circ} \mathrm{C}$ for $3 \mathrm{~d}$. Fruit abscission, fruit detachment force and fruit ethylene evolution were determined as described previously.

Statisticalanalyses. Statistical analyses included analysis of variance, regression analysis, and Duncan's multiple range test. Statistical Analysis Systems Software for PC (SAS Institute Inc., Cary, N.C.) was used for all data analyses.

Fig. 3. Effect of temperature on (A) FDF reduction and (B) fruit abscission induced by ethephon at $200 \mathrm{mg} \cdot \mathrm{L}^{-1}$ in 'Hamlin' oranges in season 2001-02. FDF and fruit abscission were determined $5 \mathrm{~d}$ after application of ethephon. Data are means \pm SE ( $n=40$ in $\mathbf{A}$, and 4 in $\mathbf{B}$, respectively).
(Fig. 2A). There was no significant difference in fruit ethylene evolution between CMNP treatment and control when the air temperature was $15.6{ }^{\circ} \mathrm{C}$ or lower; however, CMNP-treated fruit had slightly higher ethylene evolution $3 \mathrm{~d}$ after treatment. CMNP-induced fruit ethylene evolution increased markedly with

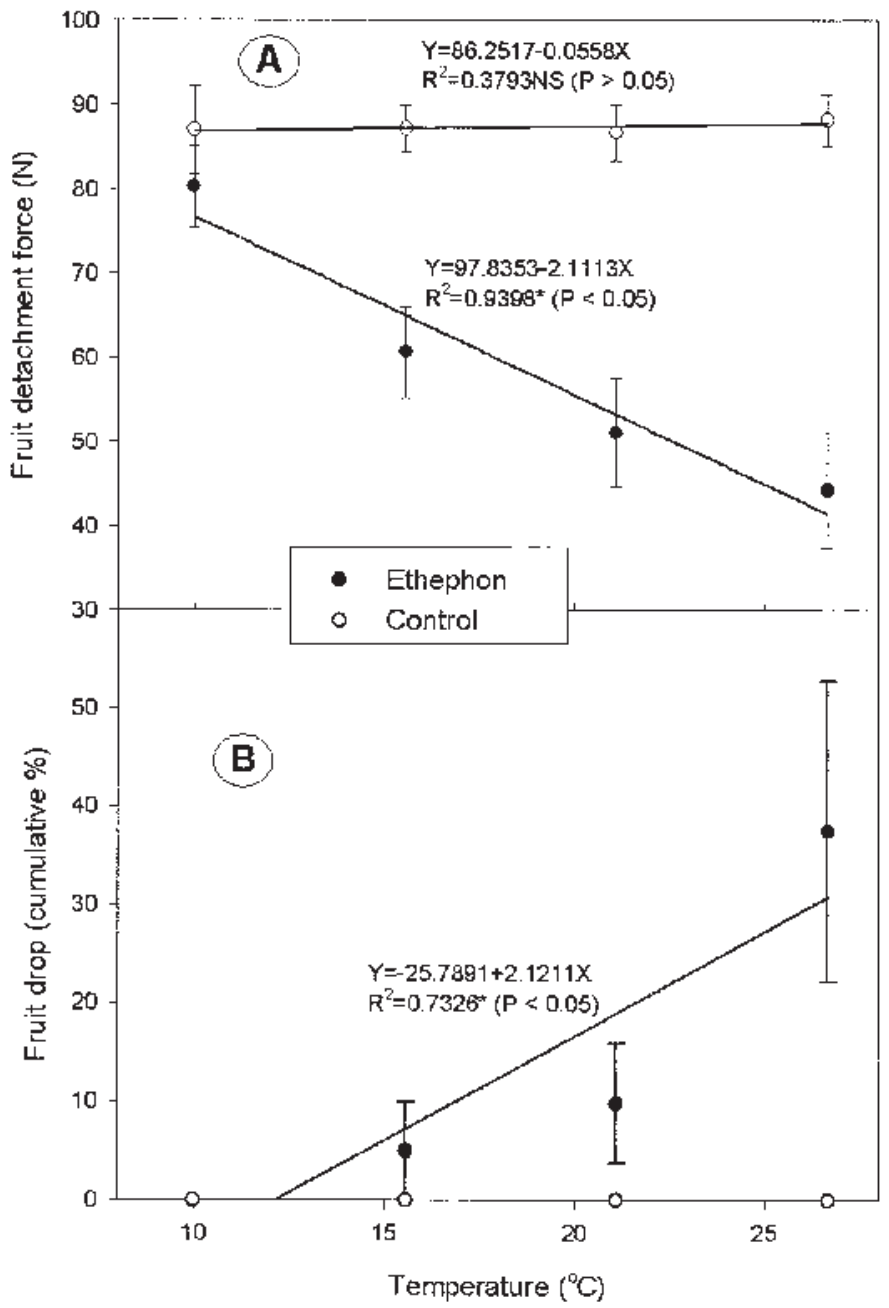




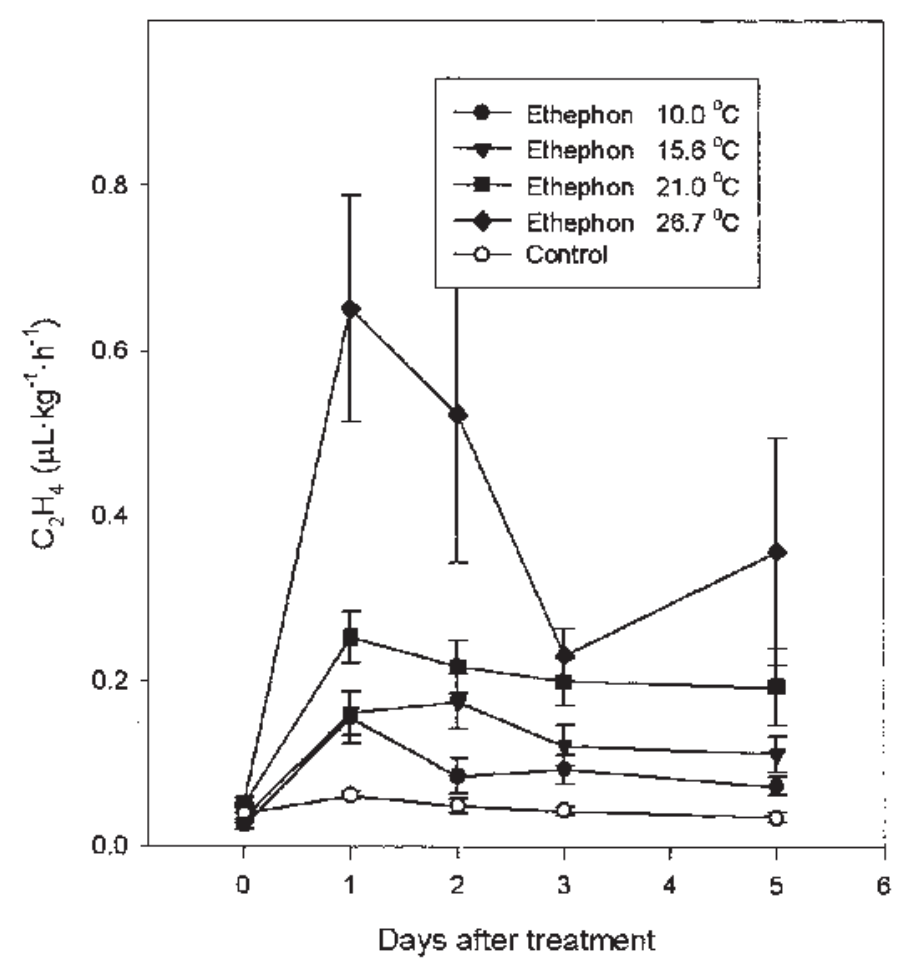

Fig. 4. Effect of temperature on ethylene evolution of mature 'Hamlin' fruit induced by ethephon at $200 \mathrm{mg} \cdot \mathrm{L}^{-1}$. Data are means $\pm \mathrm{SE}(\mathrm{n}=8)$. Without ethephon application, temperature had no significant influence on fruit ethylene evolution, so means for all controls were showed.

the increase in air temperature from 15.6 to $26.7^{\circ} \mathrm{C}$. Peak fruit ethylene evolution occurred 2 and $3 \mathrm{~d}$ after application. CMNP did not significantly enhance leaf ethylene evolution (Fig. 2B) and leaf abscission (data not shown) regardless of air temperature. Without CMNP application, temperature had no effect on leaf ethylene evolution (data not shown).

EFFECTS OF TEMPERATURE ON THE RESPONSE OF ORANGES TO ETHEPHON IN SEASON 2001-02 (EXPT. 2). Ethephon had no effect on either FDF or fruit abscission when the air temperature was maintained at $10^{\circ} \mathrm{C}$ (Fig. $3 \mathrm{~A}$ and B). However, FDF of ethephontreated fruit decreased from $\approx 88$ to $\approx 44 \mathrm{~N}$ and fruit abscission increased from 0 to $\approx 38 \%$ as the air temperature increased from 10 to $26.7^{\circ} \mathrm{C}$. Ethylene evolution from ethephon-treated fruit was slightly higher than that of control fruit when the temperature was $10{ }^{\circ} \mathrm{C}$ (Fig. 4). Ethephon-induced fruit ethylene evolution increased rapidly with increasing air temperature. Peak fruit ethylene evolution occurred $1 \mathrm{~d}$ following application in most cases. Ethephon application had no effect on leaf ethylene evolution and leaf abscission when air temperature was $10^{\circ} \mathrm{C}$ (Fig. 5A and B). However, ethephon-induced leaf ethylene evolution and leaf abscission were increased with increasing air temperature. Peak leaf ethylene evolution occurred 1 or $2 \mathrm{~d}$ after application.

EFFECTSOFTEMPERATUREONTHERESPONSEOFORANGESTOCMNP IN SEASON 2002-03 (EXPT. 3). CMNP slightly reduced FDF from $\approx 100$ to $\approx 80 \mathrm{~N}$ when the day/night temperature was $15.6 / 10{ }^{\circ} \mathrm{C}$ (Fig. 6A). FDF was markedly decreased by CMNP as the day/night temperature increased from $15.6 / 10$ to $21 / 10^{\circ} \mathrm{C}$. Increasing both the day and night temperatures to $26.7 / 15.6^{\circ} \mathrm{C}$ slightly reduced FDF further. Fruit abscission was not influenced by CMNP at $15.6 / 10{ }^{\circ} \mathrm{C}$ (Fig. 6B). However, fruit abscission caused by CMNP increased with the increase in temperature from 15.6/10 to $26.7 / 15.6^{\circ} \mathrm{C}$. Fruit ethylene evolution induced by $\mathrm{CMNP}$ was

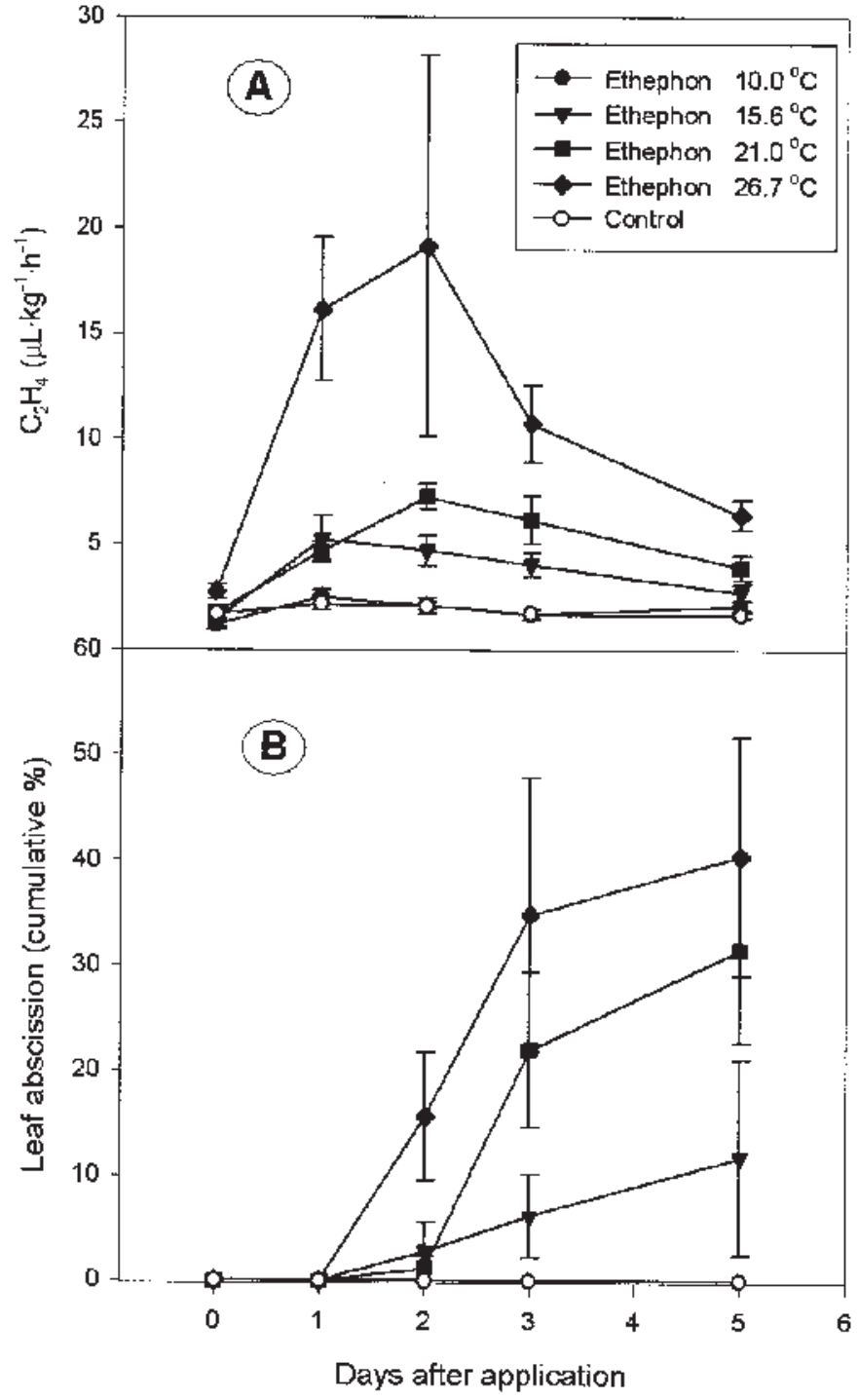

Fig. 5. Effect of temperature on (A) leaf ethylene evolution and (B) leaf abscission induced by ethephon at $200 \mathrm{mg} \cdot \mathrm{L}^{-1}$ in 'Hamlin' oranges in season 2001-02. Data are means \pm SE ( $n=8$ in $\mathbf{A}$, and 4 in $\mathbf{B}$, respectively). Without ethephon application, temperature had no significant effect on leaf ethylene evolution, so means for all controls were showed. Legend in $\mathbf{A}$ applies to $\mathbf{B}$.

low at $15.6 / 10^{\circ} \mathrm{C}$ and increased markedly when the temperature increased from $15.6 / 10{ }^{\circ} \mathrm{C}$ to $26.7 / 15.6{ }^{\circ} \mathrm{C}$ (Fig. 6C).

EFFECTS OF DAYS AT 21/10 OR 26.7/15.6 ${ }^{\circ} \mathrm{C}$ ON THE RESPONSE OF ORANGES TO CMNP(EXPT. 4). Fruit had a poor response to CMNP and FDF of CMNP-treated fruit was reduced $\approx 20 \%$ when the trees were maintained at $21 / 10{ }^{\circ} \mathrm{C}$ for $2 \mathrm{~d}$ and then at $10 / 10{ }^{\circ} \mathrm{C}$ for another $3 \mathrm{~d}$ (Fig. 7A). A marked reduction in FDF occurred in response to CMNP when the trees were kept at $21 / 10^{\circ} \mathrm{C}$ for $3 \mathrm{~d}$ and then at $10 / 10^{\circ} \mathrm{C}$ for another $2 \mathrm{~d}$. CMNP did not cause a further reduction in FDF as the days at $21 / 10^{\circ} \mathrm{C}$ increased from 3 to $5 \mathrm{~d}$. CMNP-induced fruit abscission increased slightly with increasing days at $21 / 10^{\circ} \mathrm{C}$ (Fig. 7B). CMNPdecreased FDF from $\approx 100$ to $<30 \mathrm{~N}$ when the trees were held at $26.7 / 15.6^{\circ} \mathrm{C}$ for $1 \mathrm{~d}$ followed by $10 / 10^{\circ} \mathrm{C}$ for $4 \mathrm{~d}$ (Fig. $7 \mathrm{C}$ ). FDF of CMNP-treated fruit decreased to $<15 \mathrm{~N}$ when the trees were maintained at 26.7/15.6 ${ }^{\circ} \mathrm{C}$ for $3 \mathrm{~d}$ or longer. Fruit abscission caused by CMNP increased markedly as days at $26.7 / 15.6{ }^{\circ} \mathrm{C}$ increased from 1 to $5 \mathrm{~d}$ (Fig. 7D). Fruit ethylene evolution induced by CMNP was low when trees 


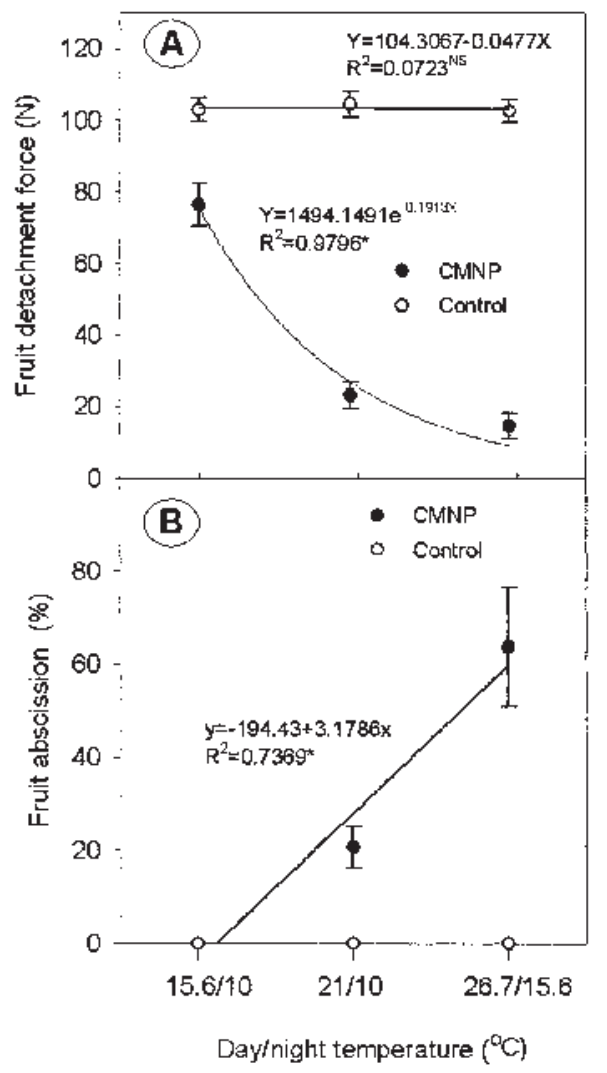

were maintained at $21 / 10^{\circ} \mathrm{C}$ for $2 \mathrm{~d}$ followed by $10 / 10{ }^{\circ} \mathrm{C}$ for another $3 \mathrm{~d}$. CMNP caused a marked increase in fruit ethylene evolution when the days at $21 / 10^{\circ} \mathrm{C}$ increased from 2 to $5 \mathrm{~d}$ (Fig. 8A). CMNP-induced fruit ethylene evolution also increased as days at 26.7/15.6 ${ }^{\circ} \mathrm{C}$ increased from 1 to $3 \mathrm{~d}$ (Fig. 8B). Fruit ethylene evolution was not further enhanced by CMNP as days at $26.7 / 15.6{ }^{\circ} \mathrm{C}$ increased from 3 to $5 \mathrm{~d}$.

INTERRUPTION BY $1 \mathrm{~d}$ OF LOW TEMPERATURE FOLLOWING APPLICATION OF CMNP ON THE RESPONSE OF ORANGES TO CMNP (EXPT. 5). At $21 / 10^{\circ} \mathrm{C}, \mathrm{CMNP}$ significantly reduced FDF to $<25 \mathrm{~N}$ and markedly enhanced fruit ethylene evolution regardless of an occurrence of one day of low temperature at $10 / 10{ }^{\circ} \mathrm{C}$ (Fig. 9A and $\mathrm{B}$ ). The rise in ethylene evolution was delayed $\approx 24 \mathrm{~h}$ in fruit of trees interrupted by $10 / 10^{\circ} \mathrm{C}$ on day 2 of the $5-\mathrm{d}$ trial. However, peak ethylene evolution occurred on the same

Fig. 7. The effect of days at $21 / 10{ }^{\circ} \mathrm{C}$ or $26.7 / 15.6{ }^{\circ} \mathrm{C}$ followed by $10 / 10{ }^{\circ} \mathrm{C}$ on $(\mathbf{A}$ and $\mathbf{C})$ fruit detachment force (FDF) reduction and (B and $\mathbf{D})$ fruit abscission induced by CMNP at $200 \mathrm{mg} \cdot \mathrm{L}^{-1}$ in 'Hamlin' oranges in season 2002-03. FDF and fruit abscission were determine $5 \mathrm{~d}$ after application of CMNP. Legend in $\mathbf{B}$ applies to all figures.Data are means $\pm \mathrm{SE}(\mathrm{n}=$ 40 in $\mathbf{A}, 4$ in $\mathbf{B}, 40$ in $\mathbf{C}$, and 4 in $\mathbf{D}$, respectively). Ns, ${ }^{*}$ Nonsignificant or significant at $P \leq 0.005$.

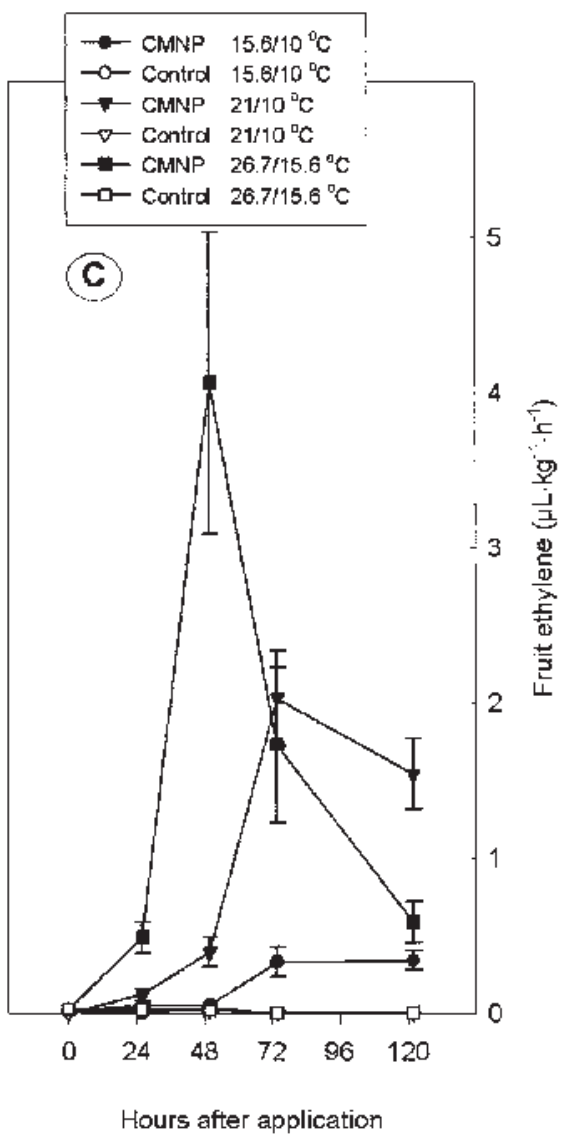

Fig 6. Effect of temperature on (A) fruit detachment force (FDF), (B) fruit abscission, and (C) fruit ethylene evolution induced by CMNP at $200 \mathrm{mg} \cdot \mathrm{L}^{-1}$ in 'Hamlin' oranges in season 2002-03. FDF and fruit abscission were determined $5 \mathrm{~d}$ after application of CMNP. Data are means \pm SE ( $n=40$ in $\mathbf{A}, 4$ in $\mathbf{B}$, and 8 in $\mathbf{C}$, respectively). ss, Nonsignificant or significant at $P \leq 0.005$.

day in all three treatments. There was no significant difference in the peak value of CMNPinduced fruit ethylene evolution between fruit from trees interrupted by $24 \mathrm{~h}$ of $10 / 10^{\circ} \mathrm{C}$, but fruit from trees held at $21 / 10^{\circ} \mathrm{C}$ without interruption were significantly higher.

\section{Discussion}

The response of mature 'Hamlin' orange fruit to CMNP and ethephon was temperaturedependent. Poor fruit loosening response was observed when temperatures were held constant for $5 \mathrm{~d}$ at 15.6 and $10{ }^{\circ} \mathrm{C}$ with CMNP or ethephon applications, respectively. FDF of CMNP or ethephon-treated fruit decreased as temperature increased thereafter. The pattern of efficacy with these two abscission materials indicate different uptake and/or action mechanisms. Ethephon directly releases ethylene by degradation after it is absorbed into tissue that has a $\mathrm{pH}$ value of above 4.5 (Olien and Bukovac, 1978). Ethephon indiscriminately enters most tissues contacted, and therefore it affects

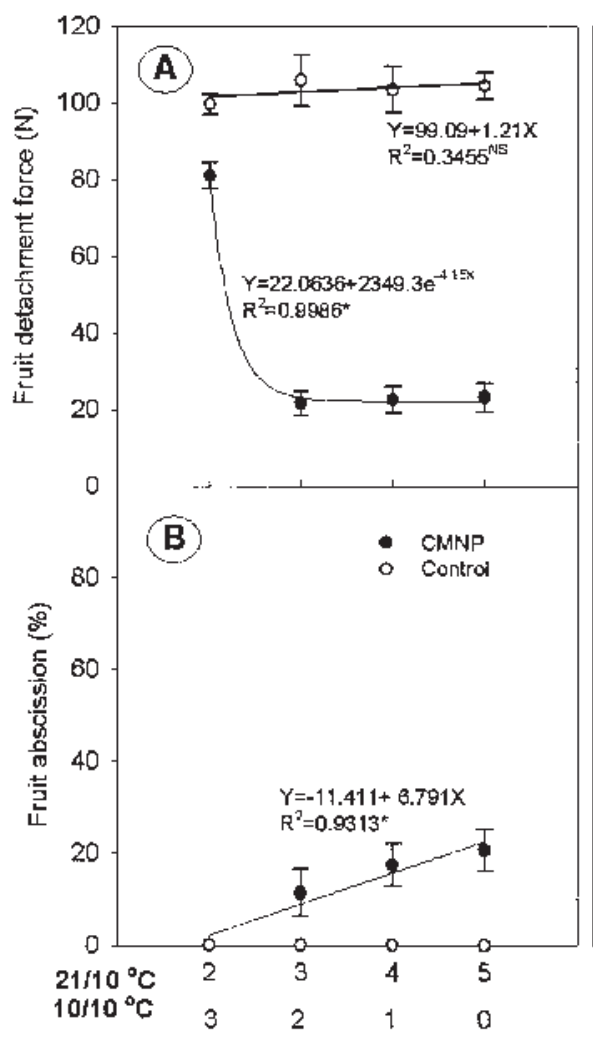

Days at $21 / 10^{\circ} \mathrm{C}$ and then at $10 / 10^{\circ} \mathrm{C}$

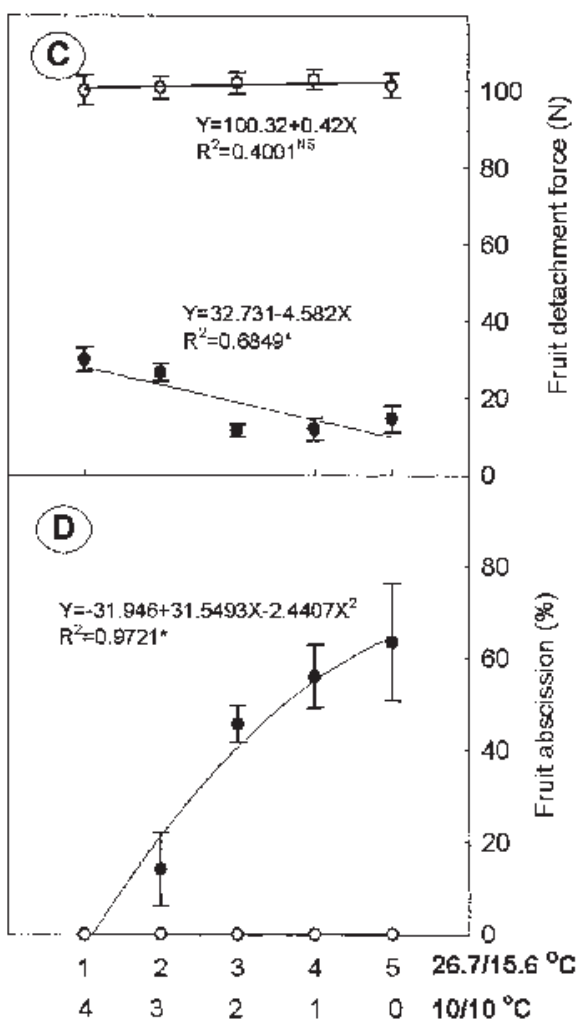

Days at $26.7 / 15.6^{\circ} \mathrm{C}$ and then at $10 / 10^{\circ} \mathrm{C}$ 


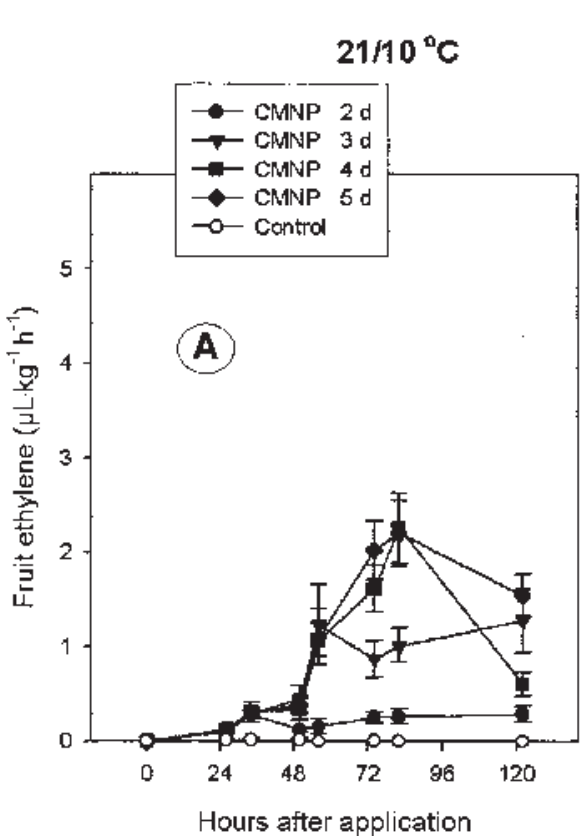

Fig. 8. The effect of different days at (A) $21 / 10{ }^{\circ} \mathrm{C}$ or $(\mathbf{B}) 26.7 / 15.6{ }^{\circ} \mathrm{C}$ and then at $10 / 10^{\circ} \mathrm{C}$ on the fruit ethylene evolution induced by CMNP at $200 \mathrm{mg} \cdot \mathrm{L}^{-1}$ in 'Hamlin' oranges in season 2002-03. Data are means \pm SE $(n=8)$. Without CMNP application, temperature had no effect on fruit ethylene evolution, so means for all controls were showed.

abscission in tissues that are capable of responding to ethylene. The mode of action of CMNP remains unknown. However, its pattern of efficacy suggests that uptake and/or action once inside fruit tissues requires temperatures above $15.6^{\circ} \mathrm{C}$.

Leaf abscission that resulted from ethephon application also increased with increasing temperature, and excessive leaf abscission occurred when the temperature was above $21^{\circ} \mathrm{C}$. It has been reported that the fruit abscission response of cherries to ethephon is temperature-dependent (Olien and Bukovac, 1978; Wittenbach and Bukovac, 1973), and ethephon caused excessive leaf abscission and gummosis when the temperature was above $20^{\circ} \mathrm{C}$ (Bukovac et al., 1969; Olien and Bukovac, 1978 ). The mature fruit-specific abscission compound CMNP (Yuan et al., 2001; Burns 2002) did not induce leaf drop at any temperature. Poor CMNPuptake and/or rapid detoxification may be responsible for lack of activity in leaves.

Ethylene evolution was positively correlated with abscission compound-induced citrus fruit and leaf abscission, and this agrees with other reports (Holm and Wilson, 1977; Kossuth and Biggs, 1977; Wheaton et al., 1977; Yuan et al., 2001). When temperature during and after application was held below $18{ }^{\circ} \mathrm{C}$ for CMNP or $15.6{ }^{\circ} \mathrm{C}$ for ethephon, ethylene evolution from fruit and leaves was also low and abscission minimal. However, increasing temperature above these values led to a sharp increase in ethylene evolution of CMNP or ethephon-treated fruit and ethephon-treated leaves and consequently fruit loosening, but in some cases, excessive leaf abscission with ethephon treatment. In leaves, CMNPhad little effect on ethylene evolution regardless of tem-

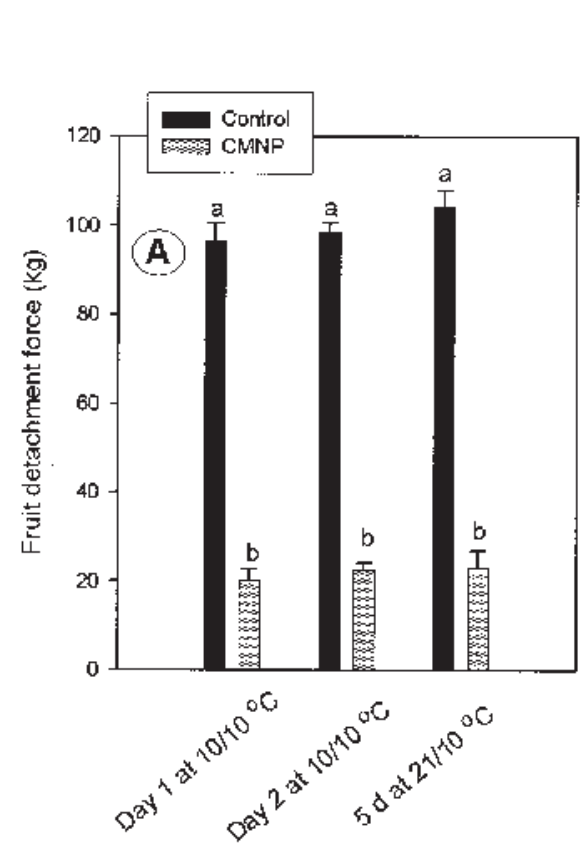

perature during or following application, and no leaf abscission occurred.

Increasing temperatures resulted in increased fruit ethylene evolution, but 2.5 to 3 times more ethylene was evolved by fruit at its peak than was necessary for maximum fruit loosening. For example, 3 times more ethylene was evolved from fruit treated with CMNP or ethephon at $24{ }^{\circ} \mathrm{C}$ than $21{ }^{\circ} \mathrm{C}$, although a similar reduction in FDF was achieved. This suggests that these abscission materials induce an overproduction of ethylene, which may serve to amplify the abscission response. CMNP-treated fruit produced much more ethylene and the reduction in FDF much greater than in fruit treated with ethephon. Ethylene promotes many downstream abscission events, including cell wall hydrolase gene expression and activity, and PR-protein gene expression (Brown, 1997; Roberts et al., 2002). These events are likely to be involved with preparing the organ for separation and protecting the abscission layer from invasion by pathogens (Bleecker and Patterson, 1997; Roberts et al., 2002; Wu and Burns, 2003). It is widely believed that ethylene initiates abscission (Brown, 1997; Roberts et al., 2002). Ethephon chemically breaks down to ethylene as it enters plant tissue, and it is this first burst of ethylene that is thought to initiate abscission. It is believed that CMNP injures the peel, and wound ethylene produced is thought to cause abscission (Davies et al., 1976; Kossuth and Biggs, 1977). In fact, the difference between ethephon (day 1) and CMNP (day 2) in timing of peak ethylene evolution could be due to the initial rate of these different mechanisms. It is visually apparent that CMNP causes damage to the

Fig. 9. Fruit detachment force (FDF) (A) and fruit ethylene evolution (B) either at $21 / 10^{\circ} \mathrm{C}$ for $5 \mathrm{~d}$ or interrupted by $1 \mathrm{~d}$ at $10 / 10^{\circ} \mathrm{C}$ during the first or second day following application of $200 \mathrm{mg} \cdot \mathrm{L}^{-1} \mathrm{CMNP}$ in 'Hamlin' oranges in season 2002-03. Bars represent SE mean. For FDF, means followed by the same letter were not significantly different at $P \leq 0.05$. 
peel on the blossom end where the spray solution accumulates before it dries. We observed that this peel damage was also promoted by increased temperature (data not shown). However, in some cases, peel damage is absent but fruit abscission will still occur. CMNP may wound peel early after application and before visual peel damage appears. If wound ethylene immediately after application is responsible for initiating abscission, the ethylene could be derived from peroxidized membranes damaged by CMNP (Knudson et al., 1994). The amount of ethylene necessary to initiate abscission is likely to be below the detection limit using conventional gas chromatography.

Interest in CMNP as an abscission material for Florida citrus has recently intensified, and research that addresses key issues such as temperature that may affect successful management and integration into mechanical harvesting systems is needed. Trees were exposed for $5 \mathrm{~d}$ to several defined day/night temperature regimes in an attempt to explore efficacy of CMNP at temperatures common during a typical harvest season in Florida. Under these conditions, the response of mature 'Hamlin' orange fruit depended on the duration of exposure to temperatures above $15.6^{\circ} \mathrm{C}$ following application. As temperatures increased above this point, the duration of exposure to temperatures required to effectively loosen fruit decreased. At least three days of exposure to 21/10 ${ }^{\circ} \mathrm{C}$, or $30 \mathrm{~h}$ of temperatures at $21^{\circ} \mathrm{C}$, were necessary for CMNP to reduce FDF to the estimated threshold $(<50 \mathrm{~N})$ for complete fruit removal by trunk-shaking mechanical harvesters, whereas only one day of exposure to $26.7 / 15.6{ }^{\circ} \mathrm{C}$ was enough to effectively loosen fruit. The ability of CMNP to induce fruit loosening was not influenced by the occurrence of one day of $10 / 10{ }^{\circ} \mathrm{C}$ during or following application. Higher temperature exposure time may promote optimum uptake and/or action of CMNP once in the tissues. Interestingly, one day of exposure to $10 / 10^{\circ} \mathrm{C}$ immediately following CMNP application gave identical efficacy to exposure to $21 / 10^{\circ} \mathrm{C}$. This suggests that significant uptake occurred either into the symplast or through the cuticle to the apoplast/symplast interface at $10^{\circ} \mathrm{C}$ to promote fruit loosening once temperatures returned to $21^{\circ} \mathrm{C}$.

In conclusion, temperature during and following application of ethephon and CMNP is a critical factor affecting field performance of these two compounds. To effectively loosen fruit, temperature should be monitored during and following application of these two compounds to ensure adequate efficacy.

\section{Literature Cited}

Biddle, E., D.G.S. Kerfoot, Y.H. Kho, and K.E. Russell. 1976. Kinetic studies of the thermal decomposition of 2-chloroethylphosphonic acid in aqueous solution. Plant Physiol. 58:700-702.

Bleecker,A.B. and S.E. Patterson. 1997. Last exit: senescence, abscission and meristem arrest in Arabidopsis. Plant Cell 9:1169-1179

Brown, K.E. 1997. Ethylene and abscission. Physiol. Plant. 100: 567-576.

Bukovac, M.J., F. Zucconi, R.P. Larsen, and C.D. Kesner. 1969. Chemical promotion of fruit abscission in cherries and plums with special reference to (2-chloroethyl)phosphonic acid. J. Amer. Soc. Hort. Sci. 94:226-230.

Burns, J.K. 2002. Using molecular biology tools to identify abscission materials for citrus. HortScience 37:459-464.

Burns, J.K., U. Hartmond, and W.J. Kender. 1999. Acetolactate synthase inhibitors increase ethylene production and cause fruit drop in citrus. HortScience. 34:908-910.

Davies, F.S., W.C. Cooper, and R.E. Holm. 1976. The effect of four abscision chemicals on orange fruit and leaf ethylene production. J. Amer. Soc. Hort. Sci. 101:651-653.

Denney, J.O. and G.C. Martin. 1994. Ethephon tissue penetration and harvest effectiveness in olive as a function of solution $\mathrm{pH}$, application time, and BA or NAA addition. J. Amer. Soc. Hort. Sci. 119: $1185-1192$.

Flore, J.A. and M.J. Bukovac. 1982. Factors influencing absorption of ${ }^{14} \mathrm{C}$ (2-chloroethyl) phosphonic acid by leaves of cherry. J. Amer. Soc. Hort. Sci. 107:965-968.

Goren, R. 1993. Anatomical, physiological, and hormonal aspects of abscission in citrus. Hort. Rev. 15:145-182.

Holm, R.E. and W.C. Wilson. 1977. Ethylene and fruit loosening from combinations of citrus abscission chemicals. J. Amer. Soc. Hort. Sci. 102:576-579.

Kazokas, W.C. and J.K. Burns. 1998. Cellulase activity and gene expression in citrus fruit abscission zones during and after ethylene treatment. J. Amer. Soc. Hort. Sci. 123:781-786.

Kender, W.J. 1998. The Florida experience with citrus abscission chemicals, p. 52-57. In: J.K. Burns and W.J. Kender (eds.). Proc. Citrus Abscission Workshop, 3-4 Feb. 1998, Citrus Res. and Edu. Ctr., Lake Alfred, Fla.

Kender, W.J., U. Hartmond, R. Yuan, L. Pozo, and A. Grant. 2000. Factors influencing the effectiveness of ethephon as a citrus fruit abscission agent. Proc. Fla. State Hort. Soc. 113:88-92.

Knudson, F.D.A., A. Campa, H.A. Stefani, and G. Cilento. 1994. Plant hormone ethylene is a Norrish type II product from enzymatically generated triplet 1-butanal. Proc. Natl. Acad. Sci. 91: 410-412.

Kossuth, S.V. and R.H Biggs. 1977. Fruit removal force, cellulase, and ethylene production in Release and ethephon-treated oranges. J. Amer. Soc. Hort. Sci. 102:609-612.

Olien, W.C. and M.J. Bukovac. 1978. The effect of temperature on rate of ethylene evolution from ethephon and from ethephon-treated leaves of sour cherry. J. Amer. Soc. Hort. Sci. 107:965-968.

Roberts, J.A., Elliot, K.A., and Z.H. Gonzalez-Carranza. 2002. Abscission, dehiscence, and other cell separation processes. Annu. Rev. Plant Biol. 53:131-158.

Wheaton, T.A., W.C. Wilson, and R.E. Holm. 1977. Abscission response and color changes of 'Valencia' oranges. J. Amer. Soc. Hort. Sci. 102: $580-583$.

Wilson, W.C. 1973. A comparison of cycloheximide with a new abscission chemical. Proc. Fla. State Hort. Soc. 86:56-60.

Wittenbach, V.A. and M.J. Bukovac. 1973. Cherry fruit abscission: Effect of growth substances, metabolic inhibitors and environmental factors. J. Amer. Soc. Hort. Sci. 98:348-351.

$\mathrm{Wu}, \mathrm{Z}$. and J.K. Burns. 2003. Isolation and characterization of a cDNA encoding a lipid transfer protein expressed in 'Valencia' orange during abscission. J. Expt. Bot. 54:1183-1191.

Yuan, R., U. Hartmond, and W.J. Kender. 2001. Physiological factors affecting response of mature 'Valencia' orange fruit to CMN-Pyrazole. I. Effects of young fruit, shoot, and root growth. J. Amer. Soc. Hort. Sci. 126:414-419. 